\title{
Paleobiology of an Ediacaran acanthomorphic acritarch
}

\author{
SAMUEL F. V. DOMINO, CORENTIN C. LORON, MARIE \\ CATHERINE SFORNA, VINCENT CALERS AND \\ EMMANUELLE J. JAVAUX
}

Université de Liège

Presenting Author: s.domino@uliege.be

The Ediacaran is a crucial time of changes in climatic and redox conditions, nutrient availability, and diversification of eukaryotes, including planktonic algae and the first unambiguous metazoans. During this period, new and highly diverse organic-walled eukaryotic microfossils appear worldwide, but their identity remains enigmatic. They are called the "Doushantuo-Pertatataka type Acanthomorphic acritarchs" (DPA). Their morphological complexity (diverse types of processes expanding from the vesicle wall) evidences their eukaryoticity. Several hypotheses for their affinity have been proposed, tentatively interpreting a few of these microfossils as eggs of metazoans [1,2] or cysts of chloroplastid green algae [2-5], but they remain ambiguous.

To test these hypotheses, we present a morphological, ultrastructural and spectroscopic characterisation of one of the most emblematic DPA acritarchs, Gyalosphaeridium pulchrum. Such analytical combination has never been performed all together on a DPA taxon. The fossils come from the Munta-1 drillcore from the Tanana formation in the eastern Officer basin in Australia. Quantitative analyses [6] of microfossils through the drillcore revealed assemblages dominated by simple smooth-walled sphaeromorphs, and less abundant but very diverse and exquisitely preserved acanthomorphs, previously reported [7]. Drawing on our analyses and previous work, we discuss the possible diagnostic combinations of characters to pinpoint the clade to which the microfossils may belong. This approach, extended to more DPA taxa, will permit to constrain the appearance of eukaryotic clades in the Ediacaran and their role in the complexification of late Precambrian ecosystems. It will also provide guidelines for future identification of similarly enigmatic microfossils, frequent in Precambrian and Paleozoic strata.

[1] Cohen, Knoll \& Kodner (2009), Proceedings of the National Academy of Sciences 106, 6519-6524.

[2] Willman (2009), Geobiology 7, 8-20.

[3] Marshall, Javaux, Knoll \& Walter (2005), Precambrian Research 138, 208-224.

[4] Moczydłowska \& Liu (2021), Geological Magazine, doi:10.1017/S0016756820001405.

[5] Willman \& Moczydłowska (2007), Lethaia 40, 111-123.

[6] Calers (2020), Diversification de la biosphère après un impact de météorite (Acraman, Australie) au Néoprotérozoïque, M. Sc. thesis, Université de Liège.

[7] Grey (2005), Memoirs of the Association of Australasian 